Artikel Penelitian

\title{
Identifikasi MRSA pada Diafragma Stetoskop di Ruang Rawat Inap dan HCU Bagian Penyakit Dalam
}

\author{
Rizkia Chairani Asri ${ }^{1}$, Roslaili Rasyid ${ }^{2}$, Edison $^{3}$
}

\begin{abstract}
Abstrak
Methicillin-resistant Staphylococcus aureus (MRSA) merupakan bakteri yang sering ditemukan sebagai bakteri penyebab infeksi nosokomial. Infeksi MRSA selain mengakibatkan bertambahnya mortalitas dan morbiditas juga menambah jumlah biaya perawatan karena semakin lamanya waktu rawat dan tambahan biaya pengobatan. Laporan RSUP Dr. M. Djamil Padang menunjukan kasus infeksi MRSA yang tinggi, terdapat 200 kasus yang tercatat sejak bulan Januari 2014 sampai Juni 2014. Stetoskop merupakan alat medis yang sering digunakan oleh dokter dan telah dilaporkan dapat mejadi sumber penyebaran infeksi MRSA. Tujuan penelitian ini adalah untuk mengetahui gambaran MRSA pada diafragma stetoskop di Ruang Rawat Inap dan HCU, yang memiliki laporan kasus MRSA terbanyak daripada ruangan lainnya. Penelitian ini merupakan studi deskriptif yang menggunakan teknik total sampling dan dilakukan pada 74 sampel stetoskop di bagian Penyakit Dalam. Isolat diambil dari swab diafragma stetoskop lalu dilakukan uji resistensi menggunakan cefoxitin. Hasil penelitian didapatkan adanya koloni MRSA pada 22 stetoskop $(64,7 \%)$ di ruang rawat inap dan 8 stetoskop $(72,7 \%)$ di HCU. Persentase stetoskop positif MRSA lebih tinggi pada HCU daripada ruang rawat inap. Banyaknya stetoskop positif MRSA menunjukan pentingnya pembersihan stetoskop setelah berkontak dengan pasien.
\end{abstract}

Kata kunci: MRSA, diafragma stetoskop, bagian penyakit dalam

\begin{abstract}
Methicillin-resistant Staphylococcus aureus (MRSA) is a majority pathogen of nosocomial infection. MRSA infections not only associated with high mortality and morbidity rate, but also with high cost of health care due to the length of stay in the hospital and additional treatment costs. Report shows RSUP Dr. M. Djamil Padang have a high cases of MRSA infection, there were 200 cases recorded since January to June 2014. Stethoscopes are one of the most commonly used medical devices and have been reported to be potential sources of MRSA infection. The objective of this study was to identify MRSA on diaphragm of stethoscopes in inpatient room and HCU, which had a most cases of MRSA infection in RSUP Dr. M. Djamil Padang. This descriptive study using total sampling technique, 74 stethoscopes were collected from Internal Medicine Division. Swab sample was taken from the surface of diaphragm of the stethoscopes for cefoxitin disk testing to detect MRSA. Results showed that 22 stethoscopes $(64,7 \%)$ in inpatient room positive for MRSA and 8 stethoscopes (72,7\%) in HCU positive for MRSA. The percentage of positive stethoscope of MRSA is higher in HCU than inpatient room. The numbers of stethoscopes with MRSA positive confirm the importance of cleaning stethoscopes after contact with the patient
\end{abstract}

Keywords: MRSA, stethoscope diaphragm, internal medicine division

Affiliasi penulis: 1. Prodi Profesi Dokter FK Unand (Fakultas Kedokteran Universitas Andalas Padang), 2. Bagian Mikrobiologi FK Unand, 3. Bagian IImu Kesehatan Masyarakat FK Unand,

Korespondensi: Rizkia Chairani Asri, Email: rizkiacasri@ymail.com, Telp: 08116627488

\section{PENDAHULUAN}

Infeksi nosokomial yang kini disebut dengan infeksi yang berhubungan dengan pelayanan kesehatan atau Health - care Associated Infections 
(HAls) merupakan masalah utama yang dihadapi oleh rumah sakit.. ${ }^{1}$ Infeksi ini mengakibatkan 99.000 kematian setiap tahunnya di Amerika Serikat. Selain menambah morbiditas dan mortalitas, HAls juga menambah jumlah biaya perawatan karena semakin lamanya waktu rawat dan tambahan biaya pengobatan. Amerika Serikat mengeluarkan biaya mencapai US $\$ 4,5$ miliar per tahun untuk menangani HAls. $^{2}$

Staphylococcus aureus (S.aureus) merupakan penyebab infeksi rumah sakit yang tersering. ${ }^{3}$ Setelah pengenalan methicillin pada tahun 1960, terbentuk strain baru, yaitu Methicillin-resistant Staphylococcus aureus (MRSA) yang menjadi endemik di beberapa rumah sakit. MRSA sering ditemukan sebagai penyebab infeksi nosokomial. Proporsi infeksi nosokomial terkait MRSA pada Intensive Care Unit (ICU) meningkat dari $2 \%$ pada tahun 1974 menjadi $64 \%$ pada tahun $2004 .^{1}$

Selama 13 tahun (1993-2005) infeksi MRSA meningkat di Amerika Serikat. Pada tahun 2005 terdapat 368.600 kasus MRSA di rumah sakit seluruh Amerika Serikat. Keadaan ini menunjukan peningkatan sebesar $30 \%$ dibandingkan pada tahun 2004. ${ }^{4}$ Prevalensi infeksi MRSA di Asia Tenggara cukup bervariasi, yaitu: $33.5 \%$ di Thailand, $13 \%$ di Singapura dan di Indonesia pada tahun 2006 sebesar $23,5 \%{ }^{5-7}$

Jumlah kasus infeksi MRSA di RSUP Dr. M. Djamil adalah 200 kasus yang tercatat sejak bulan Januari 2014 sampai Juni 2014. Terdapat 109 (54,5\%) kasus yang berasal dari bagian Penyakit Dalam. Ruangan dengan kasus MRSA terbanyak adalah ruang rawat inap pria bagian Penyakit Dalam dengan jumlah infeksi 44 kasus. Infeksi MRSA terlihat selalu meningkat, pada bulan Januari adalah 20 kasus, sedangkan pada bulan Mei menjadi 51 kasus, namun mengalami penurunan pada bulan Maret. ${ }^{8}$

Transmisi infeksi juga dapat terjadi melalui peralatan medis, salah satu alat medis yang sering digunakan adalah stetoskop.Outbreak infeksi HAls telah dilaporkan berkaitan dengan stetoskop. ${ }^{9}$ Pembersihan stetoskop selalu menjadi hal yang diabaikan. Berdasarkan suatu penelitian dari tiga puluh petugas kesehatan yang diwawancara, terdapat dua belas orang tidak pernah membersihkan stetoskop sama sekali dan hampir seluruhnya tidak membersihkan stetoskop setelah berkontak dengan pasien. $^{10}$ Hal ini membuat mudahnya kolonisasi MRSA pada permukaan stetoskop.

MRSA memiliki kemampuan untuk tetap hidup pada permukaan yang kering dalam waktu 7 hari sampai 7 bulan. ${ }^{11}$ MRSA yang telah terpapar dengan permukaan yang kering kurang dari sepuluh hari tetap bersifat virulen dan dapat menyebabkan infeksi. ${ }^{12}$

Kolonisasi MRSA sering ditemukan pada nares anterior, aksila, inguinal, dan rektum. Kontak langsung dengan bagian tubuh ini saat pemeriksaan umum atau pemeriksaan rutin membuat stetoskop memiliki potensi besar sebagai tempat kolonisasi MRSA. Pemakaian tanpa dibersihkan setelah berkontak dengan pasien akan memudahkan terjadinya infeksi silang MRSA antar pasien melalui transfer koloni MRSA dari diafragma stetoskop ke kulit pasien. ${ }^{13}$

Penelitian menunjukan bahwa kontaminasi stetoskop setelah kontak dengan pasien tidak dapat diabaikan. Secara keseluruhan diafragma stetoskop terkontaminasi hampir sama (atau lebih) dari tangan dokter pada bagian thenareminence. Terdapat korelasi antara kontaminasi bakteri MRSA di tangan dengan stetoskop, semakin banyak kontaminasi pada tangan akan semakin banyak pula kontaminasi pada stetoskop. $^{9}$

Penelitian tentang peranan stetoskop dalam penyebaran infeksi HAls masih sangat minim. Angka kejadian infeksi MRSA yang terus meningkat di RSUP Dr. M. Djamil Padang serta tingginya angka infeksi MRSA di bagian Penyakit Dalam membuat perlu dilakukan penelitian mengenai identifikasi Methicillinresistant Staphylococcus aureus (MRSA) pada diafragma stetoskop di ruang rawat inap dan High Care Unit (HCU) Bagian Penyakit Dalam RSUP Dr. M. Djamil Padang.

\section{METODE}

Desain penelitian ini adalah deskriptif untuk mengetahui gambaran MRSA pada stetoskop di ruang rawat inap dan HCU Bagian Penyakit Dalam RSUP Dr. M. Djamil Padang. Penelitian dilakukan pada bulan Oktober-Desember 2014 di laboratorium Mikrobiologi 
RSUP Dr. M. Djamil Padang dengan sampel swab stetoskop di ruang rawat inap dan HCU Bagian Penyakit Dalam. Populasi adalah seluruh stetoskop yang digunakan untuk memeriksa pasien di ruang rawat inap dan HCU. Teknik pengambilan sampel adalah total sampling, yaitu seluruh populasi dijadikan sampeldengan memperhatikan kriteria inklusi. Analisis data pada penelitian ini menggunakan analisis univariat untuk mengetahui distribusi gambaran hasil kultur S.aureus dan gambaran MRSA pada diafragma stetoskop.

HASIL

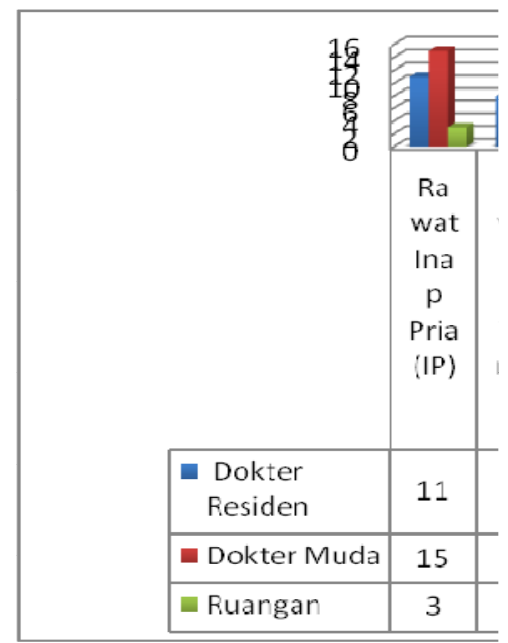

Gambar 1. Distribusi stetoskop berdasarkan lokasi dan kepemilikan

Gambar 1 menunjukkan distribusi stetoskop berdasarkan lokasi dan kepemilikan. Pada penelitian ini terdapat 74 stetoskop yang dijadikan sampel, dimana 53 stetoskop berasal dari ruang rawat inap dan 21 stetoskop berasal dari HCU.

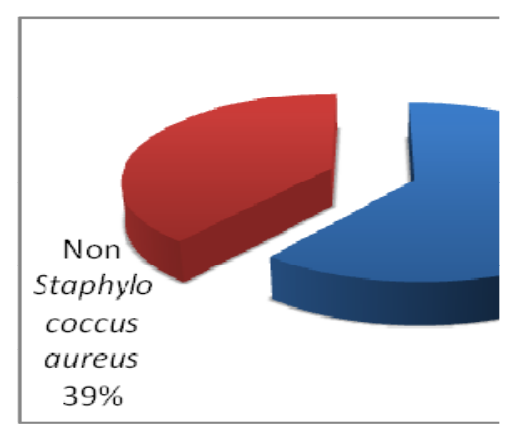

Gambar 2. Hasil kultur diafragma stetoskop
Gambar 2 menunjukan 45 sampel yang positif S. aureus $(60,8 \%)$ dan 29 sampel yang negatif $S$. aureus atau non $S$. aureus $(39,2 \%)$.

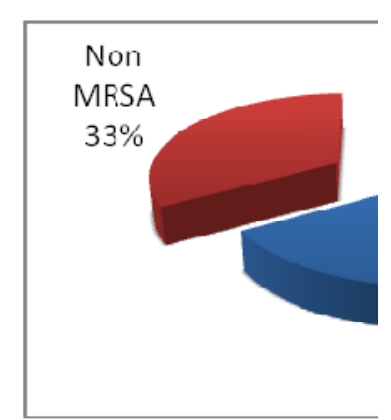

Gambar 3. Hasil Uji resistensi kultur S.aureus pada diafragma stetoskop

Gambar 3 menunjukan hasil uji resistensi dari 45 sampel yang positif S.aureus, sebagian besar merupakan MRSA.

Tabel 1. Hasil uji kultur berdasarkan lokasi

\begin{tabular}{lcccc}
\hline \multicolumn{1}{c}{ Hasil Kultur } & \multicolumn{2}{c}{ Rawat Inap } & \multicolumn{2}{c}{ HCU } \\
\hline & f & $\%$ & f & $\%$ \\
\hline $\begin{array}{l}\text { Staphylococcus } \\
\text { aureus }\end{array}$ & 34 & 64,1 & 11 & 52,4 \\
$\begin{array}{l}\text { Non } \\
\text { Staphylococcus } \\
\begin{array}{l}\text { aureus } \\
\text { Total }\end{array}\end{array}$ & 19 & 35,9 & 10 & 47,6 \\
\hline
\end{tabular}

Tabel 1 menunjukan distribusi stetoskop berdasarkan lokasi dan hasil kulturnya.Persentase stetoskop positif S.aureus pada ruang rawat inap lebih tinggi daripada $\mathrm{HCU}$, sedangkan persentase stetoskop dengan koloni Non S.aureus ditemukan lebih tinggi di $\mathrm{HCU}$ daripada di ruang rawat inap.

Tabel 2. Perbedaan hasil skrining MRSA berdasarkan lokasi

\begin{tabular}{lllll}
\hline & \multicolumn{3}{c}{ Rawat Inap } & HCU \\
\hline MRSA & $\mathbf{f}$ & $\%$ & $\mathbf{f}$ & $\%$ \\
non-MRSA & 22 & 64,7 & 8 & 72,7 \\
Total & 12 & 35,3 & 3 & 27,3 \\
\hline
\end{tabular}


Tabel 2 menunjukan gambaran MRSA dan non-MRSA pada masing-masing ruangan Hasil penelitian menunjukan persentase stetoskop positif MRSA pada HCU lebih tinggi daripada ruang rawat inap.

\section{PEMBAHASAN}

Penelitian ini mendapatkan dari 74 sampel yang ada, terdapat 29 sampel $(39,2 \%)$ non Staphylococcus aureus dan 45 sampel $(60,8 \%)$ positif Staphylococcus aureus. Penelitian yang dilakukan pada stetoskop di rumah sakit pendidikan di Michigan, 17 dari 30 sampel (57\%) positif S. aureus. ${ }^{9}$ Penelitian oleh Maluf et al, di Brazil dari 176 dari 300 s tetoskop $(57,6 \%)$ positif S.aureus. ${ }^{14}$ Penelitian oleh Uneke di Nigeria et al, 45 dari 84 stetoskop (53,6\%) positif S.aureus. ${ }^{15} \quad$ Berbeda dengan penelitian yang dilakukan oleh Pimentel di Australia, dari 11 stetoskop tidak ditemukan adanya S. aureus. ${ }^{16}$

Pada ruang rawat inap terdapat 34 dari 53 stetoskop (64.1\%) positif S.aureus, sedangkan pada HCU 11 dari 21 stetoskop (52,3\%) positif S.aureus. Walaupun tidak jauh berbeda, persentase stetoskop positif S.aureus ditemukan lebih tinggi di ruang rawat inap daripada di HCU.Lebih dari setengah stetoskop di masing-masing ruangan telah terkontaminasi dengan S.aureus.

Penelitian ini juga menemukan persentase stetoskop positif $S$. aureus yang lebih tinggi daripada kepustakaan yang ada. Berdasarkan wawancara masih banyak dokter muda atau dokter residen yang tidak pernah membersihkan stetoskopnya sehingga berpotensi menjadi tempat untuk tumbuhnya $\mathrm{S}$. aureus.

Setelah dilakukan uji resistensi dengan cakram cakram cefoxitin $30 \mu \mathrm{g}$, didapatkan 15 sampel $(33,3 \%)$ non-MRSA dan 30 sampel $(66,7 \%)$ positif MRSA. Penelitian oleh Merlin et al, di New Jersey menemukan 16 dari 50 stetoskop (32\%) petugas gawat darurat positif MRSA. ${ }^{17}$ Penelitian Killic et al di Turki menemukan 4 dari 121 stetoskop (4,3\%) positif MRSA. ${ }^{18}$ Hasil yang berbeda terjadi pada penelitian
Russel et al yaitu dari 141 sampel stetoskop tidak ditemukan adanya MRSA. ${ }^{19}$

Hasil penelitian menunjukan persentase stetoskop positif MRSA pada HCU $(72,7 \%)$ lebih tinggi daripada persentase stetoskop positif MRSA pada ruang rawat inap $(64,7 \%)$. Keadaan pasien pada HCU yang berusia lebih tua, imunosupresi dan terpapar dengan antibiotik lebih banyak membuat pasien memiliki risiko tinggi untuk terkolonisasi MRSA. ${ }^{20}$

Penelitian ini juga mendapatkan persentase stetoskop positif MRSA yang lebih tinggi daripada kepustakaan yang ada. Berdasarkan wawancara lebih dari setengah dokter tidak pernah membersihkan stetoskop dan sepertiganya tidak ingat kapan terakhir kali membersihkan stetoskop.

CDC menyarankan untuk membersihkan stetoskop secara teratur yaitu ketika setelah digunakan dan ketika stetoskop terlihat kotor dengan menggunakan alkohol 70\%. 21 Penelitian AfricaPurino et al menunjukan bahwa membersihkan stetoskop menggunakan air dan sabun, alkohol $70 \%$ atau cairan klorin mempunyai efektifitas yang sama. Dalam beberapa kepustakaan alkohol $70 \%$ lebih efektif dalam menurunkan jumlah bakteri, namun alkohol dapat mengeringkan segel karet pada diafragma stetoskop sehingga mencuci menggunakan air dan sabun bersamaan dengan mencuci tangan merupakan cara yang paling mudah dalam membersihkan stetoskop. ${ }^{10}$

Kontaminasi bakteri pada stetoskop tidak dapat diabaikan. Menurut penelitian Longtin et al diafragma stetoskop yang telah digunakan dokter untuk melakukan pemeriksaan fisik kontaminasi bakterinya hampir sama dengan kontaminasi bakteri di tangan dokter (bagian thenar eminence). Terdapat hubungan antara besarnya kontaminasi di tangan dengan kontaminasi di bakteri. $^{8}$

Stetoskop mempunyai peranan dalam menyebarkan infeksi dari satu pasien ke pasien lainnya, salah satunya adalah infeksi oleh MRSA. Pembersihan stetoskop secara rutin diharapkan bisa menurunkan angka infeksi MRSA di RSUP Dr. M. Djamil Padang. 


\section{SIMPULAN}

Gambaran hasil kultur $S$. aureus pada diafragma stetoskop di ruang rawat inap persentasenya lebih tinggi daripada $\mathrm{HCU}$.

Gambaran hasil MRSA pada diafragma stetoskop di HCU persentasenya lebih tinggi daripada di ruang rawat inap.

\section{DAFTAR PUSTAKA}

1. Scott II RD. The direct medical cost of HealthcareAssociated Infections in U.S. Hospitals and the benefit of prevention [serial online] 2009 (diunduh 13 Juli 2014). Tersedia dari: URL: HYPERLINK http://www.cdc.gov/hai/pdfs/hai/scott costpaper.pdf

2. Centers for Disease Control and Prevention. Overview of healthcare-associated MRSA [seriual online] 2010 (diunduh 17 Mei 2014). Tersedia dari: URL: HYPERLINK http://www.cdc.gov/ncidod/ dhqp/ar mrsa.html

3. Nosocomial Infection National Surveillance Service. NINSS Report on Surgical Site Infection anf Hospital-Acquired Bacteremia. Weekly. Communcable Disease Report CDR. 2000.

4. Theaker C, Ormond-Walshe S, Azadian B, Soni N. MRSA in the critically ill. Journal of Hospital Infection. 2001;48:98-102.

5. Apisarnthanarak A. Effectiveness of education and an Antibiotic-Control program in a tertiary care hospital in Thailand. Clinicial infectious disease, 2006;42:768-75.

6. Kurup A, Chlebicka N, Tan KY, Chen EX, Oon L, Ling TA, et al. Active surveillance testing and decontamination strategies in intensive care units to reduce methicillin-resistant Staphylococcus aureus infections. American Journal of Infection Control. 2010;38(5):361-67.

7. Sulistyaningsih. Uji kepekaan beberapa sediaan antiseptik terhadap bakteri Staphylococcus aureus dan Staphylococcus aureus resisten metisilin (MRSA). Bandung: Universitas Padjajaran; 2010.

8. Komite Pengendalian dan Pencegahan Infeksi Rumah Sakit RSUP Dr. M. Djamil Padang. Laporan Triwulan Infeksi MRSA; 2014.

9. Longtin $Y$, Schneider A, Pittet $D$. Contamination of
Stethoscopes and Physician's Hands After a Physical Examination. Mayo Clinic Proceedings. 2014;89(3):291-9.

10. Africa Purino FMC, Dy EER, Cornonel R. Stetoschope: a potential source of nosocomial infection. Philipine Journal of Microbiology Infection Disease. 2000;29(2):9-13.

11. Kramer A, Schwabke I, Kampf G. 2006. How long do nosocomial pathogent persist on inanimate surfaces? a systematic review. BMC Infectious Disease. 2006;6:130.

12. Boyce JM. Environmental contamination makes an important contribution to hospital infection. Journal of hospital infection. 2007;65:50-4.

13. Yang ES, Tan J, Eells S, Rieg G, Tagudar G, Miller LG. Body site colonization in paients with community-associated methicillin resistant Staphylococcus aureus and other types of S.aureus skin infection. Clinical Microbiology Infection. 2010;16(5):425-31.

14. Maluf M, Maldonado A, Bercial M, Pedrosa S. Stethoscope: a friend or an enemy. Sao Paulo Medical Journal 2001;120(1):13-5.

15. Uneke CJ, Ndukwe CD, Nwakpu KO, Nnabu RC, Ugwuoru CD, Prasopa-Plazier N. Stethoscope disinfection campaign in Nigerian teaching hospital: result of a before-and-after study. Journal of Infection in Developing Countries. 2014;8(1): 86-93

16. Pimentel J. Friend or foe(mite): contamination of stethoscope. Australian Infection Control. 2006;11(1):20-1.

17. Merlin M, Wong ML, Pryor PW, Rynn K, MarquesBaptista A, Perritt R, et al. Prevalence of methicillin-resistant Staphylococcus aureuson the stethoscopes of emergency medical service providers. Prehospital Emergency Care. 2009;13: 71-4.

18. Killic I, Ozaslan M, Karagoz ID, Zer Y, Savas E, Davotoglu $V$. The role of stethoscopes in the transmission of hospital infections. African Journal of Biotechnology. 2011;10(30): 5769-72.

19. Russell A, Secrest J, Schreeder C. Stetchoscopes as a source of hospital-acquired methiciillinreisistant Staphylcoccus aureus. American Society of Peri Anesthesia Nurses. 2012;27(2):82-7. 
20. Haddadin A, Fappiano S, Lipsett P. Methicillin resistant Staphylococcus aureus (MRSA) in the instensive care unit. Postgraduate Medicine. 2002;78:385-92 